\author{
Maria Wieruszewska-Adamczyk \\ Instytut Rozwoju Wsi i Rolnictwa \\ Polskiej Akademii Nauk
}

\title{
Wieś polska w perspektywie stulecia Refleksje rocznicowe 1918-2018
}

Rocznica odzyskania przez Polskę niepodległości sto lat temu tworzy sprzyjającą okoliczność, aby posłużyć się - obecnymi w narracji etnograficznej - kategoriami trwania i zmiany. Przez to samo nadaje się rozważaniom cechy brane pod uwagę także przez socjologów, a dotyczące przebiegu procesów społecznych. Szczególnie dwa stanowiska zasługują na przypomnienie. Pierwsze, iż jednostronne zafascynowanie zmianami odcina refleksję od namysłu nad trwałością i względną niezmiennością form ${ }^{1}$. Drugie, że ludzie tworzą społeczeństwo i historię w ramach konkretnych, przejętych z przeszłości warunków, wobec których w taki lub inny sposób się odnoszą ${ }^{2}$.

Na początku warto zwrócić uwagę na to, kto ten tekst pisze, jak pisze i dlaczego pisze? Przyjęta perspektywa, zakreślona horyzontem humanistycznych zainteresowań, w celu zmierzenia się z tytułowym zagadnieniem, jako optymalny styl narracji podpowiada wybór eseju. Przemawiają za tym następujące względy: treść tekstu odnosi się do kontekstu kultury i społeczeństwa w Polsce w minionym stuleciu, a to skłania do ujęcia bardziej syntetycznego niż analitycznego. Głównym zamiarem jest ukazanie procesu integracji i dezintegracji wsi w relacji do uwarunkowań ustrojowych. Esej lepiej niż jakikolwiek inny styl narracji nie gubi z pola widzenia człowieka, jako twórcy i nosiciela kultury, a zarazem nie kładzie tamy inspiracjom, które płyną z nowego paradygmatu kultury historycznej. Chodzi o uprawomocnienie interwencji etycznej, estetycznej i moralnej w autorskiej interpretacji zjawisk. Wybór takiego stylu z konieczności osłabia, trudne do spełnienia, oczekiwanie, aby dopełnione zostały warunki kompletności źródeł. W zamian jednak pozwala na, cenniejszą moim zdaniem, możliwość dystansowania się wobec pojawiających się ujęć badawczych, stanowisk i ocen wsi w okresie minionego stulecia ${ }^{3}$.

$1 \quad$ Socjolog Jan Szczepański pisał, że badanie samych zmian nie jest dobrą podstawą poznania stanu przyszłego, choćby z tej racji, iż nie może istnieć społeczeństwo złożone z samych nowatorów ani też wyłącznie z samych konserwatystów. J. Szczepański. O trwałości porzq̨dku życia społeczeństwa, [w:] Studia z zakresu socjologii, etnografii i historii ofiarowane Kazimierzowi Dobrowolskiemu, Kraków 1972.

2 P. Sztompka. Socjologia. Analiza społeczeństwa, Kraków 2002.

3 Zwłaszcza tych ujęć badawczych, które z rozmaitych względów upraszczały, marginalizowały, a niekiedy wręcz fałszowały obraz społeczności wiejskich w Polsce. 


\section{Przejawy integracji (1918-1939)}

Warto na początku postawić tezę, że w odrodzonym państwie polskim, które z niemałym trudem dźwigało się do niepodległego bytu, po roku 1918 na czoło procesów społecznych wysunęła się integracja. Najogólniej mówiąc, chodziło o scalenie kresów trzech państw zaborczych w jeden organizm państwowy ${ }^{4}$. Zacieranie pozostałości porozbiorowych owocowało reformami $\mathrm{w}$ istotnych dla funkcjonowania państwa dziedzinach. Dla przykładu wprowadzona w tamtym okresie reforma administracji kraju przetrwała aż do wybuchu II wojny światowej ${ }^{5}$. Na tle późniejszych - po II wojnie światowej - tendencji mnożenia liczby województw oraz zwiększania gromad przy mniejszej powierzchni kraju, wspomniana reforma administracyjna wynikała z woli wzmocnienia spójności terytorialnej ${ }^{6}$.

Niełatwa sytuacja ekonomiczna wsi, szczególnie w czasie wielkiego kryzysu lat 30. XX w., stwarzała potrzebę szeroko zakrojonych działań reformatorskich. Warto odnotować, że do powszechnej nędzy, głodu oraz zniszczeń po I wojnie światowej - jak Polska długa i szeroka - doszły masowe epidemie. Ogólnej „miserii” dopełniała trudna sytuacja mieszkaniowa wsi. Jak podaje Ignacy Tłoczek ${ }^{7}$ w 1931 roku około 11 mln osób, czyli połowa ludności wiejskiej „gnieździła się” w mieszkaniach jednoizbowych. W wielu miejscach kraju gospodarstwa poniżej 2 ha stanowiły $60 \%$ ogółu, a osławiona szachownica pól stawała się impulsem do powiedzeń, że pies, jak przysiadł na miedzy, to ogonem zamiatał zagon gospodarza. Andrzej Mencwel tak tę sytuację opisuje po latach: miedze u nas zostawiano wąskie, bo szkoda było ziemi na próżnowanie, a zagony tak małe, że siać trzeba było z płachty na ręce, gdyż siewnik na nich się nie mieścit ${ }^{8}$.

Kondycję materialną ludności w pierwszym okresie tworzenia niepodległej państwowości Melchior Wańkowicz ujął dosadnie: zaprawdę po trupach szliśmy do odbudowy. Dodawał przy tym: dzieje jednak od poczq̨tku poczęły nas pouczać (...), że skazani jesteśmy na własne wysiłki już od pierwszych lat istnienia nowego

4 Nie wnikając w szczegóły dobrze znane historykom, niwelowanie pozostałości porozbiorowych obejmowało wszystkie dziedziny życia, poczynając od wzmocnienia spójności terytorialnej, przez sferę gospodarki i kultury, po przejawy aktywności politycznej i społecznej. Niepodległa Rzeczpospolita po 1918 r. stworzyła chłopom warunki do stania się poważnq siłq politycznq i społecznq - C. Leszczyńska, O etosie chłopskim i jego znaczeniu we współczesnej Polsce, https://www.kongresobywatelski.pl/idee-dla-polski-kategoria/oetosie-chlopskim-i-jego-znaczeniu-we-wspolczesnej-polsce/ [dostęp: 30 I 2019].

5 A. Śliz, G. Rippel, „Nowe - stare” województwo opolskie, [w:] R. Geisler, B. Pawlica, M.S. Szczepański (red.), Razem i osobno. Społeczności regionalne wobec skutków reformy administracyjnej w 1999 roku. Przypadek Bielska-Białej, Częstochowy, Katowic, Opola, Tychy-Częstochowa 2004.

6 Po 1945 r. ponad dwukrotnie - w stosunku do stanu sprzed II wojny - wzrosła liczba województw (16 województw i 3.005 gmin wiejskich), podczas gdy II RP podzielona była na 7 województw i 3.195 gmin wiejskich.

7 I. Tłoczek, Dom mieszkalny na polskiej wsi, Warszawa 1985.

8 A. Mencwel, Toast na progu, Kraków 2017, s. 89. 
państwa9 . W związku z tym popularność zyskiwały idee uobywatelnienia chłopów, wspierane myślą agrarystyczną i umocowane w założeniach solidaryzmu społecznego. Chodziło o takie przekształcenie struktury agrarnej, aby zmniejszyć trudności gospodarcze i zniwelować zarzewie konfliktów społecznych na wsi. Panujące wówczas przekonanie, podzielane przez samych chłopów, że tylko ziemia cię nie zdradzi, tworzyło esencję chłopskiego doświadczenia i etosu pracy. Stąd front pracy społecznej i politycznej skierowany do wsi wynikał z tego, by uświadomiony chłop nie dawał się wyzyskać i nie popadał w takie położenie aby musiał się ratować sprzedawaniem gruntu, bo zawsze radę dać sobie potrafi nawet $w$ bie$d_{z i e^{10}}$. Stąd też uzasadniona okazała się uchwała Kongresu Stronnictwa Ludowego z grudnia 1935 roku, że podstawa przyszłego samodzielnego ustroju rolnego winien być indywidualny, samodzielny warsztat rolny oparty na prywatnej własności.

Samowystarczalne gospodarstwa chłopskie, w oparciu o spółdzielczość, skutecznie pomagały w podtrzymaniu przekonania o wyjątkowej roli chłopów w tworzeniu ustroju niepodległego państwa. To rolnicy - grupa słabsza ekonomicznie - urzeczywistniała w życiu codziennym zasady spółdzielcze, nie bez powodu nazywane córkami biedy. Nawiązując do solidaryzmu chrześcijańskiego i szeroko praktykowanych form pomocy wzajemnej w ramach wspólnego terytorium wsi - kolonii rodzin powiązanych różnymi formami działalności gospodarczej, chłopi łatwo akceptowali zasady spółdzielczości. Potwierdza to pomyślny rozwój spółdzielni kredytowych, mleczarskich, zaopatrzenia i zbytu na całym terytorium kraju. Dodać wypada, iż podwójny charakter spółdzielni - jako stowarzyszenia i jednocześnie przedsiębiorstwa - łączyły nadrzędne wartości obecne w kulturze wiejskich społeczności, takie jak: samopomoc, demokracja, równość, sprawiedliwość, solidarność, uczciwość, otwartość, odpowiedzialność ${ }^{11}$.

Warte namysłu jest przypomnienie opinii Władysława Grabskiego, który kwestionując jednostronne podkreślanie konfliktu klasowego na wsi, w tym sądów o oligarchii bogatych chłopów, pisał: wieś polska to demokracja chłopska,

9 M. Wańkowicz, Sztafeta. Ksiq̨żka o polskim pochodzie gospodarczym, Warszawa 1939, s. XIII.

10 W. Witos, Reforma rolna, „Piast” nr 40, 2 X 1921, [w:] Wincenty Witos 1874-1945, tekst i dobór ilustracji T. Bereza, M. Bukała, M. Kalisz, Rzeszów 2010. Troska o pełnoprawny udział wsi, w tym chłopów, w odbudowie niepodległego bytu państwa ilustrują słowa Witosa: Niech milionowy olbrzym chłopski wyprostuje wreszcie zgięty kark. Niech się poczuje panem u siebie, biorqc na ramiona to ciężkie zadanie. Niech potarga krępujq̨ce go kajdany niewoli i służalstwa. Niech nie słowem, ale czynem przystapi do budowania Polski nowej, tamże, s. 43.

11 W. Boguta, Spółdzielczość wiejska jako jedna z głównych form wspólnego gospodarczego działania ludzi, Warszawa 2011. Wartości te tworzyły korpus chłopskiego etosu. Znamienne, że pojęcie chłopskiego etosu włączono w idee dla Polski, nad którymi debatował XIII Kongres Obywatelski (2018). Pomijając chwalebne intencje, wypada polemicznie odnieść się do zawartości merytorycznej prezentowanych tam materiałów, które nie dotyczą etosu w ścisłym sensie tego pojęcia, natomiast posługują się tym określeniem jako łatwym zwrotem językowym. Por. C. Leszczyńska, dz. cyt. 
demokracja tych, co sami żyja z pracy rąk na własnym gruncie ${ }^{12}$. Była to praca nieodrodnie twórcza, ponieważ będqc cyklicznie ponawiana, musiała też być nieustannie odnawiana, jako mężna odpowiedź na wyzwania kapryśnej przyrody i zaskakujących dziejów ${ }^{13}$. Z pracą nierozłącznie związana była współpraca i współdziałanie. Zbiorowy tryb gospodarowania obwarowany zwyczajowymi zobowiązaniami w kręgu rodzinnym i sąsiedzkim, dotyczył - jak wspomina Mencwel - sieci kuzynów i szwagrów. Niekiedy też włączał we wspólny rytm pracy całą wieś, co - ze względu na „przymus niwowy” na skutek podziału obszaru wsi na trzy niwy w ramach tzw. trójpolówki - praktykowano do ostatnich czasów (dla przykładu we wsi Jurgów na polskiej Orawie) ${ }^{14}$.

Nie sposób wymienić, a tym bardziej opisać całości działań, które w odniesieniu do różnych poziomów - mikro-, mezo- i makrostruktury, zmierzały do scalenia zerwanej przez okres zaborów tkanki społecznej wsi w II RP. Skupienie uwagi na tym, co ludzi łączy, spaja i trzyma razem - konstytutywne dla podtrzymania więzi społecznej prawdziwie silnej, bo wspartej o wspólne wartości i organizację - upoważnia do postrzegania wsi w tamtym czasie jako zintegrowanych społeczności.

Wspomnieć warto o szeroko zakrojonych działaniach ludzi, którzy trzymali ster odpowiedzialności za II RP i w tym duchu pojmowali własną rolę pro publico bono. Jedne z takich aktywności, jako rezultat akcji scaleniowych połączonych

12 Cyt. za W. Adamski, Chłopi i przyszłość wsi. Postawy, dq̨żenia, aspiracje, Warszawa 1974, s. 231. Stanowisko W. Grabskiego jest warte przytoczenia z dwóch powodów. Po pierwsze dlatego, iż dostrzegł on wpływ doktryny marksistowskiej obciążający w sposób jednostronny poglądy badaczy na temat sytuacji społecznej wsi. Z perspektywy stulecia mogę dodać, że mniej czy bardziej uświadamiane echa wspomnianych założeń są widoczne w znamiennym rozłożeniu akcentów. Wewnętrzny potencjał wsi przysłaniały głównie wpływy zewnętrzne wpisane w proces emancypacji. W tej optyce wszystkie „dobrodziejstwa” polscy chłopi otrzymali z rqk obcych: wolność osobista od Napoleona, prawa obywatelskie i własność ziemi - od monarchów państw zaborczych. C. Leszczyńska, dz. cyt. Koncentracja na antagonistycznej strukturze społecznej z kolei marginalizowała reguły ładu społecznego i współdziałania na rzecz eksponowania konfliktów. Konflikt wysuwano na czoło relacji wewnątrzwiejskich pomiędzy różnymi grupami ludności. Konflikt przysłaniał relacje z dworem, konflikt utrudniał budowanie nowoczesnego narodu. Na tym tle nie dziwi stanowisko socjologów, którzy w oparciu o materiały historyczne kładą nacisk na napięcia i konflikty pomiędzy różnymi segmentami struktury społecznej i państwowej, by odwołać się do dychotomii kultury chłopskiej i pańskiej, szlachecko-inteligenckiej. Po drugie, pogląd Grabskiego równoważy wspomniane nachylenie. Stąd bierze się też moje świadome nawiązanie do jego ustaleń, poparte zresztą osobistym doświadczeniem badawczym. To ułatwia odparcie zarzutu, że celowe podkreślanie procesu integracji społeczności wiejskich w II RP, jakoby grzeszyło skłonnością do ujmowania wsi w kategoriach wysoce zintegrowanych wspólnot. Perspektywa antropologiczna dotycząca systemu kulturowego osłabia ten zarzut.

M. Dobrowolska. Struktury osadnicze i ich regionalne zróżnicowanie, [w:] Studia z zakresu..., s. 97. 
z kolonizacja wsi, wynikały z troski o przeciwdziałanie procesom niekontrolowanego rozpraszania osadnictwa ${ }^{15}$. Inne - głównie za sprawą księży - przyczyniały się, na ziemiach dawnych zaborów, do powstawania „wzorcowych wsi”. Jeszcze inne dotyczyły redagowania pism dla wsi.

Siły pobudzające wspomnianą aktywność miały przede wszystkim źródła wewnętrzne - endogenne. Kierowały nimi idee demokratyzacji, samoorganizacji i uobywatelnienia chłopów, znajdując w tamtym czasie oparcie w ustaleniach profesora Władysława Grabskiego, ojca socjologii wsi w Polsce. To on zwracał uwagę na podstawowo-wyjściowy charakter wsi dla tworzenia innych grup społecznych. To on podkreślał, że wieś ma w sobie siły dynamiczne. Tym samym zaprzeczał ocenom o rzekomej bierności wsi, która jakoby tylko przeżywa i przeżuwa, a nie tworzy i nie dqż̇̇ ${ }^{16}$. Nie skupiał uwagi, jak to czynili późniejsi badacze, na izolacji świadomościowej wsi, jej autarkii i homogeniczności. Nie kwestionował wprawdzie tego, iż wieś stanowi lokalną społeczność z u p e łn ą, czyli zamkniętq w sobie, obejmujq̨cq wszystkie prawie funkcje życia zbiorowego swoich członków ${ }^{17}$, lecz owa jedność i samoistność przesądzała w sposób zasadniczy o funkcjonalności całego systemu. Nie koncentrował się na katalogu cech stygmatyzujących wieś, a wypływających z przesłanek, które celowo - programowo i propagandowo - negatywnie to środowisko naznaczały.

Te ostatnie założenia - motywowane ideologicznie i doktrynalnie - mniej czy bardziej świadomie utrwaliły się zresztą w myśli socjologicznej na długie dziesiątki lat minionego wieku. Przyjmowały obraz separacji kultury „pańskiej” i „,chłopskiej”, jak u Józefa Chałasińskiego, nawiązując do socjalistycznej idei walki klasowej. Stygmatyzowały wieś jako rzekomy balast niedopasowania systemowego, szczególnie w praktykach i ideologiach: modernizacji, industrializacji, urbanizacji, które - jak wiadomo - wyznaczały azymuty rozwoju społeczeństwa w II połowie XX w. Władysław Grabski polegał na własnym, wywiedzionym z empirii, rozeznaniu wiejsko-rolniczej rzeczywistości w Polsce. Wskazywał, że pomimo faktycznego zróżnicowania majątkowego gospodarstw, jakie łatwo było zinterpretować przez pryzmat konfliktu klasowego, trwały wciąż elementy funkcjonalnej całości wsi w sensie układania swych wewnętrznych stosunków społecznych według określonego typu ${ }^{18}$. Na koniec tej części warto

15 Nota bene plaga chaosu i bezładu przestrzennego na tzw. „obszarach wiejskich” z jakim mamy do czynienia obecnie jest efektem zaniedbań - także badawczych - w sferze integracji wsi w wymiarze wspólnego terytorium, osobowych interakcji i wartości, jako koniecznych „sprzężeń zwrotnych” dla ożywienia motywacji do działania dla wspólnego dobra i aktywności dla zaspokojenia wspólnych potrzeb.

16 W. Grabski, System socjologii wsi, „Roczniki Socjologii Wsi”, t. 1, 1936, s. 71.

17 Por. S. Czarnowski, Podłoże ruchu chłopskiego, [w:] Dzieła, t. 2, Warszawa 1995 oraz K. Zawistowicz-Adamska, Przemiany więzi społecznej w społeczności lokalnej, „Roczniki Socjologii Wsi”, t. IV, 1965, s. 41.

18 Zdaniem W. Grabskiego te cechy były źródłem dynamiki w kierunku tworzenia przyszłości nie tylko swojej, ale i całego społeczeństwa, W. Grabski, dz. cyt., s. 74. 
przypomnieć, że w okresie międzywojennym tradycyjne zintegrowane społeczności wiejskie, które tworzyły całościowe układy społeczno-gospodarcze, były w Polsce silne.

\section{Trauma II wojny światowej i anomia czasów powojennych}

Procesy rozpadu, dezintegracji, dezorganizacji społeczności wiejskich w czasie wojny to efekt ogólnej brutalizacji życia. Wsie padały ofiarą bezpośrednich działań wojennych: bombardowań, podpaleń, rozmaitego rodzaju traumy wskutek przechodzenia linii frontów, ale też bolesnych doświadczeń stałej okupacyjnej represji. Odwet za pomoc udzielaną oddziałom partyzanckim skazywał mieszkańców całych wsi na brutalną eksterminację. Masowe mordy, przymusowe wysiedlenia, ciągłe obowiązkowe kontyngenty, sekwestracja majątku trwałego i nietrwałego odciskały się na życiu rodzin i funkcjonowaniu gospodarstw nie tylko chłopskich ${ }^{19}$. Ciągła przemoc, stałe narażenie utraty życia i podleganie nieustannemu terrorowi w sumie powodowało rozluźnienie obowiązujących przed wojną norm współżycia. Ludzie bali się ze sobq spotykać (...) bo ważniejsze [było - przyp. M.W.] zapewnienie sobie bezpieczeństwa ${ }^{20}$.

Na skutek gwałtownej dezorganizacji lokalnych społeczności dochodziło do załamania norm moralnych i zaniku w nich społecznej kontroli. Stan duchowy wsi zaczął się przeobrażać $w$ dwie charakterystyczne odmiany - a to życie dla siebie i życie wobec wroga. Ta dwulicowość stała się koniecznościq w utrzymaniu swojej pozycji i stanowiła samoobronę przez fizycznymi i biologicznym wyniszczeniem ludności $i^{21}$. Celnie komentuje to cytowana autorka, kiedy pisze: społeczność nie była już taka sama jak zaledwie kilka lat wcześniej, ale ludziom tej zmiany doświadczajqcym trudno było zrozumieć, z czego owo poczucie obcości wynika ${ }^{22}$.

Okres powojenny pozostawił po sobie moralnie naganne skutki okupacji. Ogólne przyzwolenie na kradzieże, rabunek, dewastację, usprawiedliwiano okolicznościami odwetu za doznane wcześniej krzywdy. Tłumaczono to biedą, niepewnością i powszechnym chaosem. Gdy ktoś im przypominał dlaczego tak niszczq, to odpowiadali, że to nie nasze, że ich to nie obchodzi, bo oni tu nie będq,

19 Oto wspomnienia losów ostatnich właścicieli majątku Walewice pomiędzy Łowiczem a Kutnem. Jak większość polskich ziemian rodzina Grabińskich herbu Pomian doświadczyła skutków reformy rolnej. Zostali wywłaszczeni bez odszkodowania i bez prawa zbliżania się do swoich posiadłości na mniej niż $30 \mathrm{~km}$. Jednym posunięciem został starty z powierzchni świat ziemiański, pomimo rozlicznych zasług pro publico bono. Nie od rzeczy będzie przypomnienie, że podczas kampanii wrześniowej 1939, a zwłaszcza w trakcie ciężkich walk nad pobliską Bzurą (9/10 września), rodzina Grabińskich w patriotycznym odruchu oddała wojsku polskiemu 20 koni z własnej hodowli. Informacja pozyskana od aktualnego kierownika zarządzającego stadniną koni w Walewicach, w maju 2017. A. Wylegała, Krajobraz po wojnie: anatomia rozpadu świata społecznego na przykładzie Polski w okresie II wojny światowej, „Studia Socjologiczne”, 3/2016, s. 142.

Tamże, s. 138. 
tylko na wiosnę pojadq do domu ${ }^{23}$. Konsekwencji takich postaw nie dało się usunąć przez długie lata powojenne. Dotyczyły one zarówno niszczenia dworów i pałaców, dużej i małej architektury, jak i infrastruktury wsi: młynów, wiatraków, spichlerzy, studni. Spajające wspólnotę lokalną podobne odniesienia do terytorium wsi, wcześniej składające się na całościowy układ ekonomiczny ${ }^{24}$, poddane anomii w rezultacie wojny i okupacji, pogłębiały ogólny chaos i dezorganizację więzi społecznej. To z kolei przekładało się na zerwanie ciągłości kulturowego przekazu w wymiarach: materialnym, społecznym i duchowym.

Przejawy anomii szczególnie silnie dotykały ludność wysiedloną i przesiedloną. Trudności odbudowania siedlisk w zupełnie innym terenie, bez odpowiednich materiałów, wiedzy i troski o to, by zachować regionalny styl architektury, ale też niemożność kultywowania własnych tradycji, zakłócały możliwości kontynuowania dotychczasowych wzorów życia. Wyobcowanie i wykorzenienie, pogłębiane na skutek wzajemnych uprzedzeń i stereotypów, które dotykały zarówno ludność napływową, jak i autochtoniczną, na przykład na Ziemiach Zachodnich, z biegiem lat ulegały osłabieniu. Przeradzały się z czasem w próby budowania tożsamości nowych wspólnot wiejskich. Nie był to jednak proces ani powszechny, ani nie przebiegał bezkonfliktowo.

Skutki przeobrażeń ustrojowych i zmiana granic po II wojnie światowej przekładały się na długi proces adaptacji, szczególnie na Ziemiach Zachodnich i na północy kraju. Krzysztof Kwaśniewski, na podstawie swoich badań na Śląsku Opolskim w okresie powojennym, tak opisywał ten problem: Nowo zasiedlone miejscowości sq̨ na ogół lepiej wyposażone, a przejęte budynki i urzq̨dzenia stojq na wyższym poziomie technicznym niż te, do których przywykła ludność napływowa. Wywołuje to często niezamierzonq konieczność przenoszenia się ludności wiejskiej do miast oraz gwałtownq rewizję dotychczasowych nawyków ${ }^{25}$. Dystans gospodarczy okazał się najważniejszym czynnikiem wpływającym na trudności integracyjne społeczności wiejskich.

Rekapitulując. Anomia rozumiana jako załamanie podstawowych wartości i norm społecznych ${ }^{26}$ naznaczyła wieś szczególnie dramatycznie podczas II wojny światowej. Okupacja, przesiedlenia i eksterminacja całych wsi skutkowały dezorganizacją, osłabieniem społecznej kontroli, prowadząc do rozpadu konstytutywnych cech wielu polskich wsi jako społeczności lokalnych. Polegało to na przerwaniu tradycji, załamaniu zwyczajowych relacji, jakie łączyły ludzi z terytorium wsi, zarazem miejscem pracy i życia rodzin rolniczych, które w zgodzie ze zwyczajowymi zobowiązaniami, w żywotny sposób podtrzymywały układ społeczno-gospodarczy wsi.

23 Tamże, s. 153.

24 Z. Sokolewicz, Niektóre sposoby opisu i tłumaczenia społeczności lokalnej, „Roczniki Socjologii Wsi”, t. IV, 1965, s. 54.

25 K. Kwaśniewski, Niektóre zagadnienia specyfiki i hierarchii problemów w badaniach problemów społeczności wiejskiej na Ślqsku, „Roczniki Socjologii Wsi”, t. IV, 1965, s. 185.

26 K. Szafraniec, Anomia, [w:] Encyklopedia Socjologii, t. 1, Warszawa 1998, s. 32. 


\section{Wieś w kręgu socjalistycznej industrializacji i urbanizacji}

W interpretacji zmian, jakie dokonały się w Polsce w okresie PRL podkreśla się dwuznaczny stosunek władzy państwowej do wsi. Ilustruje to stanowisko Włodzimierza Sokorskiego, ówczesnego ministra kultury, nawiązujące do słusznej tezy, że w historii Polski trwale obecna jest idea budowania tożsamości narodowej w oparciu o kulturę ludową. Z jednej strony wspomniany minister pisał, że kultura chłopska to bijq̨ce serce narodu. Z drugiej zaś zachęcał chłopów, aby stawali się proletariuszami ${ }^{27}$, co wpisywało się $\mathrm{w}$ plany socjalistycznej industrializacji i urbanizacji. Ludowy mandat legitymizował nową władzę, ale czyniono to wybiórczo, starając się zneutralizować sakralny kontekst ludowej kultury. Symboliczna przemoc, ideologiczne dyskryminowanie wsi, w której wciąż żywy był silny etos chłopski, prowadziły do dezintegracji społeczności wiejskich. Mimo że proces dezintegracji obejmował wszystkie konstytutywne dla wsi dziedziny życia, to nie był to ani proces całkowity, ani też nie zachodził w jednakowym tempie i zakresie we wszystkich wsiach ${ }^{28}$. W rezultacie różnicowania zawodowego ludności, pojawienia się w strukturze społecznej wsi tak zwanych chłopów-robotników, ograniczeniu ulegały kontakty wewnątrz społeczności, osłabiała się sieć wzajemnych zobowiązań w ramach sąsiedzkiej przysługi. W to miejsce wkraczała kalkulacja, prowadząca do rozerwania dwóch komplementarnych składników więzi prawdziwie silnej, a mianowicie opartej o wspólnotę wartości i organizację. Wsie nasycały się wyspecjalizowanymi związkami i zrzeszeniami opartymi o przemysłową organizację pracy. Gospodarstwa rolne zmieniały reguły działania, odchodząc od uprawy zwyczajowej na zawodowq warsztatowq (...) przedsiębiorstwo wprzęgało się w systemowe mechanizmy rynkowo-pieniężne, które swobodę gospodarowania limitowały, a [gospodarza - przyp. M.W.] zniewalały ${ }^{29}$.

Ideologia awansu społecznego, profesjonalizacji pracy, emancypacji - jako azymuty aspiracji życiowych młodych mieszkańców wsi - oznaczały opuszczenie wsi i przeniesienia się do miast, na budowy i do fabryk. To miały być miejsca narodzin nowego człowieka, który zrywał ze środowiskiem wsi, którą w oficjalnym przekazie uznawano za anachroniczne miejsce życia, gdzie zabobon, analfabetyzm, brak higieny, ogólne zacofanie odbiegały od wizji kultury socjalistycznej. Wieś w sensie propagandowym jawiła się jako wylęgarnia bogatych gospodarzy, kułaków, wrogów klasowych przyszłej przodujqcej, bojowej inteligencji $^{30}$. Ten typ postaw ilustruje jeden $\mathrm{z}$ bohaterów książki Andrzeja Mencwela. Nienawidziłem tego wszystkiego - syczał przez zęby - nienawidziłem

$\overline{27}$ W. Sokorski, O sztukę realizmu socjalistycznego, [w:] Sztuka w walce o socjalizm, Warszawa 1959, s. 145-153, cyt. za B. Brzostek, Czy folklor wszedł do śródmieścia? O motywach ludowych w PRL-u, [w:] J. Kordjak, Polska - kraj folkloru? Warszawa 2016, s. 72. J. Turowski, Przemiany tradycyjnej wiejskiej społeczność lokalnej w Polsce,, „Roczniki Socjologii Wsi”, t. IV, 1965, s. 33.

29 A. Mencwel, dz. cyt., s. 293. Industrializacja okazała się odpowiedzialna za „kolonizację” wsi w wymiarze społeczno-kulturowym. G. Foryś, Gospodarstwa i stowarzyszenia agroturystyczne w Polsce, Warszawa 2016, s. 148.

30 W. Sokorski, dz. cyt. za D. Crowley, Chłop w mieście, [w:] J. Kordjak, dz. cyt., s. 71. 
orki, wykopków, sianokosów, żniw, zwózki i wszystkiego innego, od wyrzucania gnoju w krzyżu mnie rąbało i w głowie ćmiło (...) tylko przy pasionce mogłem się uczyć i wtedy się wszystkiego nauczyłem ${ }^{31}$.

Ideologiczne dyskryminowanie wsi, a w efekcie dezintegracja społeczności wiejskich, były powodem pogłębiania się poczucia niższości, wstydu, a w konsekwencji przyjmowania przez mieszkańców wsi wzorów imitujących życie w mieście. Przejawy tych zachowań to osłabienie etosu chłopskiego, zanik wartości budujących tożsamość miejsca w wymiarach materialnych i duchowych ${ }^{32}$, niekorzystne zmiany w przestrzeni wsi - odejście od regionalizmu w architekturze. Ignacy Tłoczek pisał, że w przestrzeni wsi zapanowała szpetota $i$ wyobcowanie z narodowej kultury ${ }^{33}$. Późniejsze konsekwencje tych zmian to zachwianie struktur demograficznych, wyludnianie wsi, kryzys rolnictwa, ubytek ziemi rolnej, niekontrolowana „suburbanizacja”, bezład i chaos przestrzenny, o czym dalej.

\section{Transformacja ustrojowa po 1989 r.}

Blisko trzy dekady, jakie upłynęły od roku 1989, w którym rozpoczynała się transformacja ustrojowa, to wystarczający okres dla zbilansowania oczekiwań i realnych dokonań. Nie odbiegając od głównego wątku - a mianowicie wsi w procesie zmian - warto szerzej przyjrzeć się temu, jakie nadzieje wiązano z przejściem do gospodarki rynkowej, ustroju demokratycznego i państwa prawa na tle spełnionych i niespełnionych nadziei. Początkowa euforia budowy nowego ustroju nie pozostawiała miejsca dla głębszego intelektualnego namysłu nad rzeczywistymi szansami jego wprowadzenia. Naiwne traktowanie nowego ustroju, jako proste przeciwieństwo realnego socjalizmu, dopiero stopniowo odsłaniało swój prawdziwy charakter. Jerzy Szacki nazwał to utopijnym projektem implementacji liberalizmu po komunizmie ${ }^{34}$.

Na początku transformacji z ust doradców z Zachodu dało się słyszeć opinię, że wieś jest naszą szansą, ale rolnictwo mamy złe. Skąd brała się nadzieja dotycząca wsi? Nie można wykluczyć, że na tle zindywidualizowanego, odhumanizowanego, zdepersonalizowanego i przepełnionego konsumpcjq stylu życia wielkich

31 A. Mencwel, dz. cyt., s. 290.

32 M. Wójcik (red.), Tożsamość i „miejsce”. Budzenie uśpionego potencjału wsi, Łódź 2017, s. 8.

33 I. Tłoczek, dz. cyt., s. 11.

34 J. Szacki, Liberalizm po komunizmie, Warszawa 1994, s. 261. Dylematy i koszty transformacji z czasem ujmowano w sformułowania takie jak: imitacyjna zmiana, narzucona retoryka, odgórna modernizacja. A. Giza-Poleszczuk pisze samokrytycznie: nie przewidzieliśmy żadnej z ważnych zmian ostatnich 30 lat, bo straciliśmy zdolność prawdziwej analizy socjologicznej. Prawdziwej czyli całościowej, uwzględniajqcej szerszy kontekst, a nie tylko posługującej się kalkami z Zachodu. A. Giza-Poleszczuk, Jako socjologowie straciliśmy zdolność prawdziwej analizy, https://klubjagiellonski.pl/2018/05/20/giza-poleszczuk-jakosocjologowie-stracilismy-zdolnosc-prawdziwej-analizy-rozmowa/ [dostęp: 30 I 2019]. 
miast (...) na Zachodzie wieś polska jawiła się jako odkryta na nowo oaza „starych” zasobów ${ }^{35}$. Rolnictwo natomiast - na tle obowiązującej „produktywistycznej” jego funkcji, wspieranej analizami ekonomicznymi, które odnosiły się do wydajności pracy, kosztów produkcji - było przeważnie traktowane jako nienowoczesne, bo nietowarowe. Te rozbieżności istotnie mogły pogłębiać przestrzeń dyskusji i sporów, odkrywać coraz liczniejsze dylematy transformacji, a w efekcie utrudniać wizję harmonijnego zrównoważonego rozwoju.

Główna oś aktualnych sporów, które dotyczą wsi, sprowadza się do dwóch stanowisk. Jedno wykorzystuje argument, iż skoro nie ma samej wsi jako względnie jednolitego przedmiotu opisu, to nie ma przeciwwskazań, aby promocją aktywności na tak zwanych terenach wiejskich zajmowały się profesjonalne organizacje znane głównie z dużych ośrodków miejskich ${ }^{36}$. Przeciwny pogląd, który bierze pod uwagę historyczny sens istnienia wsi jako miejsca życia i pracy rodzin rolniczych, dostrzega na wsi walory miejsca i potencjał tożsamości wpisane w kontekst kultury ${ }^{37}$.

Można powiedzieć, iż na dnie upadku rodzi się nadzieja. Ta fraza przychodzi mi na myśl na tle coraz bardziej dotkliwych przejawów kryzysu wsi i rolnictwa, nie tylko w Europie. Objawy nadprodukcji, szkód ekologicznych, bezładu przestrzennego, przyczyniają się - siłą rzeczy - do głębszej refleksji nad optymalnym modelem rozwoju. Do głosu - także w Polsce - zaczęło dochodzić przekonanie o potrzebie takiej polityki gospodarczej, która by prowadziła do ożywienia „wiejskości” (odnowy, rewitalizacji wsi) przez pobudzanie lokalnych zasobów i byłaby - bardziej niż w przeszłości - zorientowana na kontekst lokalny. Pomysłodawcy strategii dla wiejskiej Europy jeszcze na początku transformacji kierowali się ideą równowagi między ludźmi a środowiskiem, opowiadali się za utrzymaniem gospodarki rolnej we wszystkich krajach europejskich. Wtórowały im opinie, że pozostawienie na ziemi rolników w ramach gospodarstw rodzinnych jest jedynym sposobem utrzymania walorów środowiska przyrodniczego i zachowania żywotności wsi.

Na tle wspomnianej reorientacji, zarówno w dyskursie o wsi, jak też w programach jej aktywizacji, stopniowo i nie bez oporów także w świadomości badaczy, ożywała kategoria społeczności lokalnej. Konstytutywne dla społeczności wiejskiej składowe więzi prawdziwie silnej, bo opartej o wspólnotę i organizację, $\mathrm{z}$ przeniesieniem w ocenach akcentu z ilości na jakość, ponownie zaczynają tworzyć oś narracji o wsi. Mamy do czynienia z odwróceniem wektora dezintegracji w stronę re-integracji społeczności wiejskich.

$\overline{35}$ G. Foryś, dz. cyt., s. 145.

K. Murawska, P. Sadura, Z. Włodarczyk, Wieś w Polsce 2017. Diagnoza i prognoza. Raport z badania, Warszawa 2017, s. 7.

37 Dlatego społeczności wiejskiej nie da się zredukować do funkcji „dopełnienia” miasta, M. Wójcik, dz. cyt., s. 11. 


\section{Zakończenie}

Najmocniej, w sposób najsilniej widoczny w minionym stuleciu 1918-2018, w Polsce dawał o sobie znać proces dezintegracji społeczności wiejskich. Nie przebiegał on jednak ani liniowo, ani jednokierunkowo. Nie miał też charakteru powszechnego. Cechowało go własne tempo zmian i specyficzny zakres relacji wewnątrz społeczności i z otoczeniem zewnętrznym, które było określane przez zmieniające się warunki ustrojowe państwa w poszczególnych okresach.

Najsłabiej dezintegracja widoczna była w dwudziestoleciu międzywojennym (1918-1939). Ustępowała wyraźnie nadrzędnym procesom scalania, łączenia, integracji, co było efektem działań państwa dźwigającego się do niepodległego bytu po okresie zaborów.

Okres traumy związany z II wojną światową to czas chaosu, skutków wszechobecnej anomii, a także etap wyraźnego odwrócenia procesu integracji w stronę rozkładu, rozpadu, zerwania ciągłości na wszystkich poziomach życia wsi.

Czas PRL-u przyspiesza radykalne zmiany wsi. Socjalistyczna industrializacja i urbanizacja przyczyniają się do radykalnych zmian w strukturze społecznej wsi i pogłębiają proces dezintegracji społeczności wiejskich.

Reguły transformacji po roku 1989 okazały się odgórnie przyjętym ładem społeczno-gospodarczym. Utopia programów implementacji liberalizmu po komunizmie, dylematy i koszty transformacji dopiero po 30 latach, nie bez sporów, doprowadzają do nowej narracji o wsi. Pojawiają się próby reintegracji społeczności wiejskich.

\section{Summary}

\section{Polish Village in the Perspective of the Century. Anniversary Reflections}

Disintegration of villages was the important process of social change in Poland during the Century of 1918-2018 years. It run nor in the linear nor in the one directed manner however. The process of disintegration of rural community was not universal one on the territory of Poland. It also has no unilateral effects during the period of 1918-2018.

The consolidation, connection, affiliation of economic, social and cultural domain of the State were the most characteristic trends of the period of the twenty years before of the Second World War.

The rapid changes in the earlier process of integration of rural social community took over during The Second World War and next years implemented by new policy in Poland after 1945 year.

The new rules of transformation intensify the discussion connected with problems of village and agriculture after 1989 year. Slowly, step by step, there 
were come into sight the new symptoms of the re-integration process of local village community after 30 years of transformation.

Key words: essay, integration, disintegration, re-integration, village, rural community

Adres mailowy autorki: m.wierusz@wp.pl 